\title{
Pharmacological Treatment of Alzheimer's Disease: Insights from Drosophila melanogaster
}

\author{
Xingyi Cheng ${ }^{1,2,+}$, Chaochun Song ${ }^{1,2,+}$, Yanjiao Du ${ }^{1,2}$, Uma Gaur ${ }^{1,2}$ and Mingyao Yang ${ }^{1,2, *(1)}$ \\ 1 Institute of Animal Genetics and Breeding, Sichuan Agricultural University, Chengdu 611130, China; \\ chengxingyisicau@163.com (X.C.); songchaochun@outlook.com (C.S.); yanjiaodu177@hotmail.com (Y.D.); \\ gaur.uma2906@gmail.com (U.G.) \\ 2 Farm Animal Genetic Resources Exploration and Innovation Key Laboratory of Sichuan Province, \\ Sichuan Agricultural University, Chengdu 611130, China \\ * Correspondence: yangmingyao@sicau.edu.cn; Tel.: +86-28-028-86290991 \\ + These authors contributed equally to this work.
}

Received: 19 May 2020; Accepted: 25 June 2020; Published: 29 June 2020

\begin{abstract}
Aging is an ineluctable law of life. During the process of aging, the occurrence of neurodegenerative disorders is prevalent in the elderly population and the predominant type of dementia is Alzheimer's disease (AD). The clinical symptoms of AD include progressive memory loss and impairment of cognitive functions that interfere with daily life activities. The predominant neuropathological features in $\mathrm{AD}$ are extracellular $\beta$-amyloid $(\mathrm{A} \beta)$ plaque deposition and intracellular neurofibrillary tangles (NFTs) of hyperphosphorylated Tau. Because of its complex pathobiology, some tangible treatment can only ameliorate the symptoms, but not prevent the disease altogether. Numerous drugs during pre-clinical or clinical studies have shown no positive effect on the disease outcome. Therefore, understanding the basic pathophysiological mechanism of AD is imperative for the rational design of drugs that can be used to prevent this disease. Drosophila melanogaster has emerged as a highly efficient model system to explore the pathogenesis and treatment of AD. In this review we have summarized recent advancements in the pharmacological research on AD using Drosophila as a model species, discussed feasible treatment strategies and provided further reference for the mechanistic study and treatment of age-related AD.
\end{abstract}

Keywords: Alzheimer's disease; AD model; pharmacology; signaling pathways; Drosophila

\section{Introduction}

The fragile elderly population is the main socio-economic concern of society and it is expected that by 2050 there will be 1.6 billion people over the age of 65 worldwide [1]. The process of aging is often accompanied by the occurrence of various diseases which rarely affect younger individuals, such as cardiovascular disease, cancer, and neurodegeneration. Because of the complexity and the universality of neurodegeneration, studies involving its pathogenesis and treatment continue to invite a lot of attention from the scientific community [2]. Among all the neurodegenerative disorders, Alzheimer disease (AD) is the most common form of dementia, which causes cognitive deficits, memory loss, and behavioral alterations [3]. According to the World Alzheimer Report, about 50 million people worldwide were reported to have dementia in 2018. By 2050, owing to the increase in the elderly population, this number is expected to increase to 152 million, which is three times what it is now. The cost of global social dementia was estimated to be US \$1 trillion in 2018, and this number will most likely increase to US\$ 2 trillion by 2030 [4]. Unfortunately, the pathological mechanism of AD is still elusive, and no therapeutics are available for the prevention or mitigation of the disease progression. 


\section{Pathogenesis of Alzheimer's Disease}

As one of the major neurodegenerative diseases, $\mathrm{AD}$ and its pathogenesis have been widely studied. Most of the recent studies on AD have been primarily focused on $\beta$-amyloid $(A \beta)$ and Tau protein [5-8]. Meanwhile, biologically, AD is defined by the presence of a specific neuropathological profile, which is when extracellular deposition of $\beta$-amyloid forms intraneuronal neurofibrillary tangles and aggregated hyperphosphorylated tau protein $[9,10]$. Amyloid deposition, astrogliosis, tau protein hyperphosphorylation and accumulation, neuronal dystrophy, oxidative stress, decline in acetylcholine (ACh) levels, etc., constitute the main pathological hallmarks of AD [11-15]. By studying the intercellular molecular mechanism of $A D$, researchers found that $A \beta$, Amyloid precursor protein (APP) cleavage form and microtubule-binding protein tau are three important pathogenic molecules in AD pathology [16]. Three forms of secretase can cleave APP under different circumstances. Normally, APP is cleaved by $\alpha$-secretase to produce sAPP (APPs $\beta$ ) and a C83 carboxy terminal fragment, and the sAPP molecule establishes regular signaling with synapses to maintain synaptic plasticity [17]. However, according to the amyloid hypothesis, abnormal cleavage of APP by $\beta$-secretase (BACE1) and $\gamma$-secretase results in 42 amino acid long polypeptides (A $\beta 42$ peptides), under pathological condition. Subsequently, the accumulation of $A \beta 42$ in the plaque induces a pathological cascade and eventually leads to neurodegeneration (Figure 1) $[18,19]$. On the other hand, presence of NFTs is also a noticeable characteristic of $\mathrm{AD}$, which is formed by hyperphosphorylated Tau. Multiple evidence has shown that aggregated, hyperphosphorylated forms of tau could also be a primary driver of $\mathrm{AD}$ and play a key role in promoting neuronal toxicity and neuronal loss [20-22]. Tau is a soluble protein that is naturally unfolded but, under ambient conditions, aggregates into oligomers and fibrils. Moreover, many kinases can mediate tau phosphorylation [23]. For example, inflammation in the brain can stimulate activation of mitogen-activated protein kinase (MAPK) which in turn activates the cyclin-dependent kinase- 5 (CDK-5) leading to tau hyperphosphorylation [24].

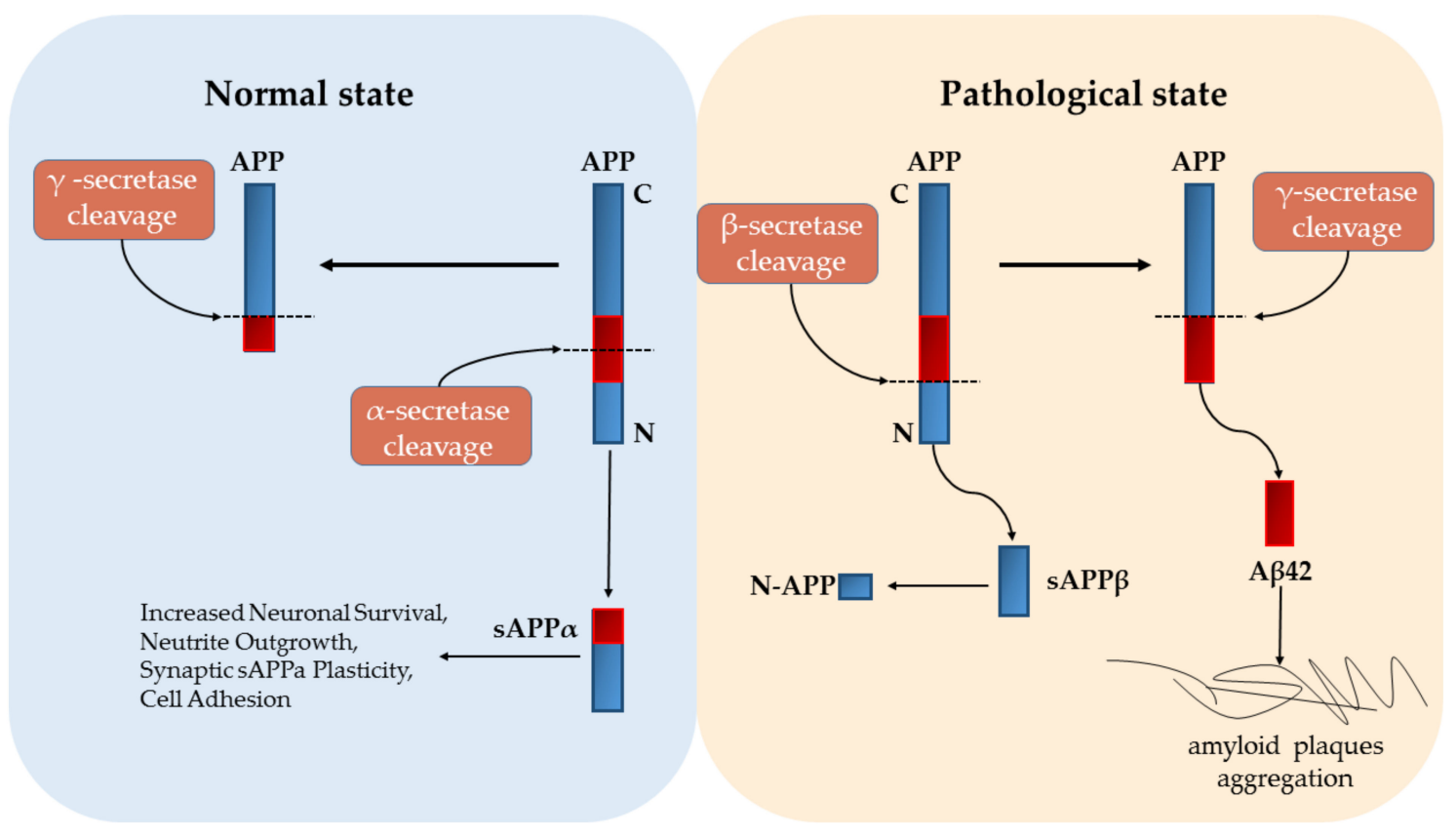

Figure 1. Amyloid precursor protein (APP) cleavage under normal and pathological states. Under normal state, APP is first cleaved by $\alpha$-secretase to produce sAPP. sAPP can help the correct transduction of synaptic signals. Conversely, under pathological state, APP is sequentially cleaved by $\beta$-secretase and $\gamma$-secretase to produce $A \beta 42$ fragment, which aggregates frequently to form plaques and eventually causes nerve cell death. 
A study by Oddo et al. suggested that clearance of $A \beta 42$ reduced tau aggregation but increasing the expression of tau had no effect on $A \beta 42$ pathology, suggesting that tau acts downstream of $\mathrm{A} \beta 42$ [25]. However, there is increasing information about the interaction between $A \beta 42$ and tau [26]. Researchers should reconsider the relationship between $A \beta 42$ and tau in order to discover tau-targeted therapeutics and to explore the mechanisms by which $\beta$-amyloid peptides elicit synaptotoxicity.

\section{Application of Drosophila as Alzheimer's Disease Model}

In order to facilitate an intensive understanding of the different pathways and pathogenesis involved in AD, many appropriate disease models have been developed and applied, including mouse, Caenorhabditis elegans and Drosophila melanogaster [27-29]. Drosophila is an excellent model for studying genetic and cell biology pathways in complex biological processes [30]. Owing to a complex brain, short lifespan and the relative ease in genetic manipulation, Drosophila can be a useful neurodegenerative invertebrate model [31].

Any vertebrate gene can be specifically expressed in specific tissues and cells of Drosophila using GAL4/UAS expression system [32], and nearly $70 \%$ of human pathogenic genes have homologous genes in Drosophila [33]. In order to study the associated mechanisms, the pathogenic gene responsible for $\mathrm{AD}$ can be inserted downstream of UAS to construct transgenic flies, which can overexpress the AD susceptibility gene at specific times and in specific tissues (Figure 2A) [34]. According to transgenes inserted, there are two main types of Drosophila AD model. The first and foremost type of Drosophila $\mathrm{AD}$ model is based on $\mathrm{A} \beta$ proteotoxicity. Although Drosophila contains homologous genes of human APP gene and an integral of the $\gamma$-secretase complex also has $\beta$-secretase, it cannot produce its own endogenous $A \beta$ protein $[35,36]$. In that case, by over-expression of $\beta$-secretase-like protein, the cleavage of $\mathrm{dAPP} 1$ can be initiated to produce a fragment which is similar to human $A \beta$ peptide and results in age-dependent behavioral deficits and neurodegeneration [35]. Along with inducing the endogenous production of $A \beta$ peptide, the transgenic Drosophila producing $A \beta 42$ peptide can also be used to study its toxicity and related neurodegeneration. Researchers constructed the transgenic Drosophila expressing human APP protein (HAPP), human $\beta$-secreted protein (hBACE) and Drosophila $\gamma$-secreted presenilin (dPsn), and showed an age-dependent neurodegenerative phenotype [37,38]. Interestingly, the toxic effect of detected A $\beta 42$ in the fly was considerably higher in the APP-BACE1 transgenic flies compared to the $A \beta 42$ transgenic flies, implying that the crucial points for $A \beta 42$ proteotoxicity are the location and situation in which the peptide is generated and not the actual production level of $A \beta 42$ peptide in the flies [39]. Simultaneously, tau plays a vital role in the formation of neurofibrillary tangles and neurotoxicity [40]. Aggregated and hyperphosphorylated forms of tau could be the primary driver of neurodegeneration in AD [41]. The second type of Drosophila AD model, the Tau-based transgenic Drosophila model, has been established, which can express abnormal human tau protein. This model displayed various symptoms of human degenerative diseases, including abnormal phosphorylation and aggregation of tau protein in neurons, and showed similar circadian and sleep deficits as seen in $\mathrm{AD}$ patients [42,43]. It has been suggested that aggregated $\mathrm{A} \beta 42$ stimulates tau phosphorylation and toxicity in AD pathogenesis, but the mechanisms are still elusive and many factors could cause tau phosphorylation [43]. Rising evidence supports the proposal that tau phosphorylation at Ser262 plays a critical role in A $\beta 42$-induced tau toxicity in A $\beta 42$ and tau co-expression Drosophila model [44]. Meanwhile, subsequent research showed that the loss of axonal mitochondria would phosphorylate tau at Ser262 which further induced A $\beta 42$ toxicity in the pathogenesis of AD [45].

In the line with the above, most of the transgenic Drosophila AD models display a shortened lifespan [34]. So far, the most effective way to rescue AD has not been explored, but Drosophila models are often used to screen drugs with potential effects on lifespan shortening and AD phenotype [46]. In this review, we will focus on the main signaling pathways related to AD pathology and their corresponding pharmacological treatment using Drosophila models (Figure 2B). We hope to provide further inspiration for the development of new drug targets and new Drosophila AD models. 
a

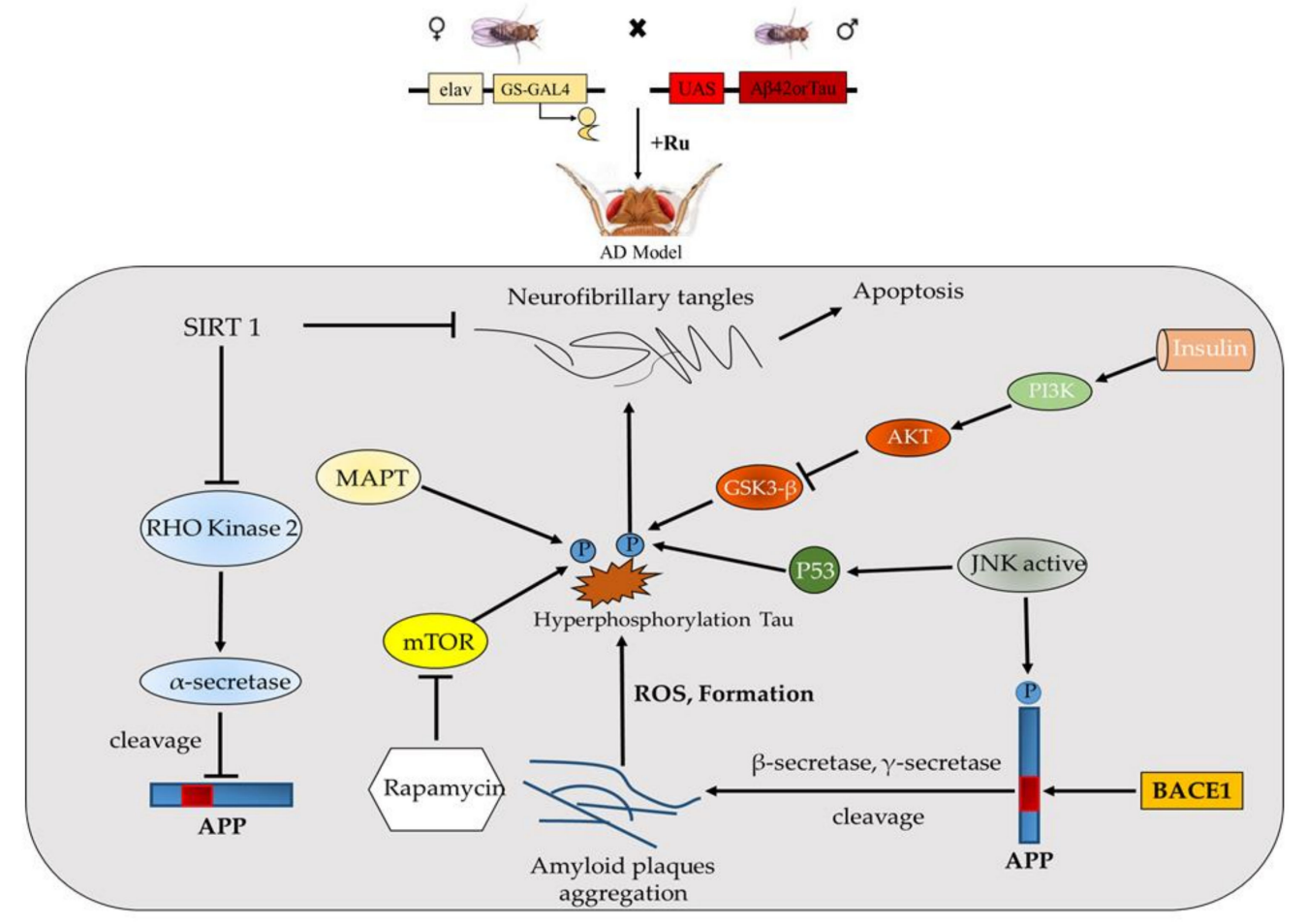

Figure 2. (a) Expression of A $\beta 42$ peptide or tau protein in the Drosophila nervous system by UAS/GAL4 system (The yeast transcriptional activator Gal4 can be used to regulate gene expression in Drosophila by inserting the upstream activating sequence (UAS) to which it binds next to a gene of interest [47]). When females carrying a reporter gene with UAS (UAS-GFP) are mated with males carrying a GAL4 driver, progeny containing both elements of the system are produced. The presence of GAL4 in specific tissue will drive expression of the UAS reporter gene in a corresponding pattern. (b) Major signaling pathways involved in AD pathology of Drosophila.

\section{Pharmacological Treatment of Alzheimer's Disease Using Drosophila as a Model}

Numerous drugs have been tested to prevent and cure Alzheimer's disease in an animal model $[2,48,49]$. The symptoms in most AD animal models are onset in adults; therefore, targeted drugs are considered to act directly on $\mathrm{AD}$ via ameliorating $\mathrm{AD}$-related symptoms, rather than slowing down aging to delay the onset of $\mathrm{AD}[3,50]$. We will discuss relevant drugs and their targeted signaling pathways in detail as follows.

\subsection{IIS Signaling Pathway}

The insulin/insulin-like growth factor 1 signaling pathway (IIS) is highly conserved and the most important signaling pathway known to regulate animal development and aging-related diseases. Evidence shows that insulin/insulin-like growth factor (IGF) signaling is important for neuron growth, synaptic maintenance, and neuroprotection [51], and insulin resistance is related to the tau hyperphosphorylation and increased level of A $\beta 42$ [52], which is supposed to trigger AD. Diabetes is also a risk factor for AD and dementia, and insulin plays an important role in both conditions. Metformin has been used as an antidiabetic for many years. Early studies suggested that metformin reduces $\mathrm{BACE} 1$ transcription and $\mathrm{A} \beta$ production in neuronal cell lines, and found that this effect is insulin-dependent [52]. Recent study showed that metformin can promote new neuron growth in a series of in-vitro and in-vivo experiments [53]. Unfortunately, no evidence has shown benefits of metformin in the flies AD model, and some researchers have suggested that insulin signaling may just serve as a promising target for Alzheimer's treatment in non-diabetes patients [54]. There is also some evidence that insulin treatment can meliorate cognition, but worsen AD pathology. That is why we 
need more irrefutable evidence to verify the connection between AD and insulin signaling. Recently, Huang et al. showed that A $\beta$ causes accumulation of fly ILPs (Insulin-like peptides) and elevation of fly InR-S6K signaling, but knock down of ILPs, InR or the downstream components of S6K can effectively suppress $A \beta$ toxicity. This indicates that utilizing $S 6 \mathrm{~K}$ as a drug target to reduce insulin and insulin signaling can effectively reduce, instead of aggravating, the A $\beta$ pathology. Although many upstream factors may alter $A \beta$ toxicity, insulin signaling is the main downstream executor of $A \beta$ toxicity. Therefore pharmacological intervention of the IIS pathway may serve as a promising target for the treatment of AD [55]. Along with S6K, there are some other important targets downstream of insulin signaling that influence AD pathology.

AKT plays important roles in neuronal survival, growth, polarity, synaptic plasticity and circuitry. Dysregulation of the AKT is the basis of many neurodevelopmental, neurocognitive, neuropsychiatric and neurodegenerative diseases [56]. Many studies have already proved that pharmacological inhibition of AKT activity can increase lifespan and healthspan in Drosophila [57]. Through genetic manipulations, Chen et al. created AKT RNAi and A $\beta 42$ co-expressing Drosophila for pan-neuronal genes. Downregulation of AKT improved learning performance and increased the survival period in A $\beta 42$ flies and, similarly, AKT inhibitor MK2206 also rescued the lifespan and learning deficit of A $\beta 42$ flies [58]. A few other AD models also support this conclusion. After drug administration, nitazoxanide stimulated autophagy and promoted $A \beta$ clearance by inhibiting AKT signaling in-vivo and in-vitro [59]. In contrast, decreased $A \beta$ levels and $A \beta$ deposition in brain were seen in salidroside fed A $\beta$-Drosophila, which protected neuron-cells from A $\beta$ toxicity by upregulating AKT signaling [60]. Low dose Ionizing radiation suppressed the developmental defects and locomotive dysfunction, but had no effect on survival rates and longevity of $A \beta 42$-expressing flies [61]. As far as the current results are concerned, the connection between $\mathrm{AKT}$ and $\mathrm{AD}$ becomes bewildering. AKT regulates neuronal survival and morphology and it is well established that with aging AKT activity increases. In that case, it is important to understand the role of abnormal AKT signaling in AD processing. It becomes imperative to explore whether the reduced activity of AKT can protect neuronal survival or increased activity is related to aging and promotes $\gamma$-secretase activity, leading to the cleavage of APP to and production of $A \beta$. In addition, it is necessary to underline whether increased $A \beta$ activates more AKT to further increase $\gamma$-secretase activity and promotes APP processing [53]. We need more lines of evidence in order to explore appropriate drugs that target AKT.

Glycogen synthase kinase-3 (GSK-3) is a serine/threonine-specific protein kinase, also a major molecule involved downstream of insulin signaling. In the central nervous system (CNS), GSK-3 $\beta$ is the most abundant and is involved in diverse areas of physiology and pathology, including cellular metabolism and neurogenesis [62]. GSK-3 $\beta$ is the main kinase of tau protein, and its activation promotes tau phosphorylation and $\mathrm{A} \beta$ plaque deposition [63]. AD patients exhibit higher levels of circulating GSK-3 $\beta$, therefore inhibition of GSK-3 activity has become a potential target for the treatment of various neurological diseases [64], and a variety of AD models have been developed to verify its effect. Lithium, a feasible GSK-3 inhibitor, is widely used in the treatment of psychiatric conditions. After administration, Lithium rescued $A \beta$ toxicity caused by direct regulation of $A \beta 42$ peptide levels but not mRNA levels [34]. Interestingly, this effect appears to be at least in part mediated by tau-independent mechanisms, and only at low dose prolonged the lifespan of mutant $A \beta 42$ flies [65]. Flavonoid compounds Amentoflavone inhibited A $\beta 42$ induced neurotoxicity in animal and cellular models through AMPK/GSK-3 $\beta$-mediated pyroptosis suppression [66]. As mentioned before, BACE1 dysregulation results in AD pathogenesis, and GSK-3 $\beta$ regulates BACE1 transcription, thereby facilitating A $\beta$ production in AD. AR-A014418 (ARA), a specific inhibitor of GSK-3 $\beta$, reduced BACE1 promoter activity and gene expression in cell culture. In-vivo, ARA decreased BACE1 expression and markedly reduced $\beta$-secretase processing of APP and A $\beta$ production, resulting in inhibition of neuritic plaque formation and amelioration of memory deficits [67]. Researchers proposed that by utilizing genetic manipulation to reduce GSK-3 in Drosophila larval neurons, AD induced synapse reduction can be recovered. In-vitro, GSK-3 $\beta$ inhibitor SB 415286 (SB) increased the density of synapses in 
hippocampal neurons in dose dependent manner [68]. Interestingly, a study in tau transgenic Drosophila model, after Salidroside treatment, showed improved longevity, locomotor activity, downregulated $p$-tau and fewer vacuoles in the mushroom body, but upregulated level of p-GSK-3 $\beta$ [49]. The catalytic activity of GSK- $3 \beta$ is regulated by phosphorylation at two different sites; phosphorylation at Ser9 site inactivates GSK-3 $\beta$; however, phosphorylation at Tyr216 increases its catalytic activity [69]. This indicates that targets may have multiple regulatory sites and different sites may have completely different effects on the AD process. This is a big challenge for drug development. An exhaustive list of the drugs that target insulin signaling pathway to treat AD in Drosophila model is shown in Table 1.

Table 1. Overview of compounds targeting the insulin/insulin-like growth factor 1 signaling pathway (IIS) in Drosophila Alzheimer's disease (AD) models.

\begin{tabular}{cccc}
\hline Treatment & Mode of Action & Effects & References \\
\hline MK2206 & Inhibiting AKT activity & $\begin{array}{c}\text { Improved A } \beta 42 \text { induced early } \\
\text { death and learning deficit }\end{array}$ & {$[58]$} \\
\hline Salidroside & $\begin{array}{c}\text { Upregulating AKT and } \\
\text { GSK-3 } \beta \text { activity }\end{array}$ & $\begin{array}{c}\text { Decreased A } \beta \text { levels and A } \beta \\
\text { deposition, protected neuron-cells }\end{array}$ & {$[49,60]$} \\
\hline Ionizing radiation & Upregulating AKT activity & $\begin{array}{c}\text { Suppressed developmental defects } \\
\text { and locomotive dysfunction }\end{array}$ & [61] \\
\hline Lithium & Inhibiting GSK-3 activity & $\begin{array}{c}\text { Lifespan extension, rescued A } \beta \\
\text { toxicity, reduced protein synthesis }\end{array}$ & [65] \\
\hline SB 415286 & Inhibiting GSK-3 $\beta$ activity & Promotes synapse formation & {$[68]$} \\
\hline
\end{tabular}

\section{2. mTOR Signaling Pathway}

Mammalian target of rapamycin, mTOR, is a serine/threonine protein kinase, composed of two complex subtypes namely mTORC1 and mTORC2 [70]. Many studies have discussed the involvement of mTOR in life processes, including regulation of gene translation, development of neuronal stem cells, protein degradation, apoptosis and autophagy [71-73]. In CNS, the corresponding function of mTOR is regulated by many receptors or channels on the neuronal membrane [74].

In animal $\mathrm{AD}$ models, $\mathrm{A} \beta$ protein aggregation increases the expression of mTOR signaling, and conversely, reducing mTOR signaling can also bring down the expression of $A \beta$ protein $[75,76]$. Rapamycin is a prevalent inhibitor of mTOR which effectively ameliorates neurodegeneration including improved cognitive deficit [77], increases A $\beta$ clearance by reducing APP generation and downregulating $\beta$ - and $\gamma$-secretase activity, and reduces Tau hyperphosphorylation by upregulating the levels of insulin-degrading enzyme [78,79]. Owing to the outstanding therapeutic benefits, rapamycin has been the center of disease research and drug development. For example, the long-term inhibitory effect of rapamycin on mTOR in AD mice, not only enhances learning and memory, but also regulates its behavior throughout life [80]. mTOR influences the onset and progression of neurodegenerative diseases by inhibiting autophagy $[81,82]$ and autophagy can enhance neuronal survival by removing A $\beta 42$ accumulation [83]. Hyperphosphorylated tau activates mTOR in AD flies, resulting in activation of cell cycle regulators and induction of neuronal death. A related study showed that reducing mTOR signaling expression or intake of rapamycin can reduce tau aggregate and improve related mobility impairments [84].

However, some reports suggested that knocking out of mTOR signaling impaired the synaptic plasticity, which can be reversed by up-regulation of mTOR and the loss of mTOR activity may also cause atrophy of AD neurons [85]. Salidroside treatment initiated mTOR activation in AD flies [60]. Considering the role of mTOR in memory formation and function in promoting cognition, it comes as no surprise that excessive activation as well as inactivation of mTOR might be the pathological mechanism behind the cognitive loss and AD progression. Therefore, it is necessary to keep mTOR at a precise balance point. In this case, treating AD with mTOR as the target, the timing of medication may be a crucial factor. Furthermore, the side effects of rapamycin and its analogue cannot be ignored, 
like reduced fertility and impaired locomotor activity [86]. Additionally, further research is needed to examine the beneficial effects of rapamycin in $\mathrm{AD}$ flies before deciding whether it can be a potential drug for clinical treatment of AD.

\subsection{Sirtuin Pathway}

Sirtuin, a cluster of conserved proteins encoded by the SIRT genes, is a type of protein that depends on NAD+ activation and has deacetylation activity [87]. The sirtuin family consists of seven members, including SIRT1, SIRT2, SIRT3, SIRT4, SIRT5, SIRT6, and SIRT7, which can regulate diverse physiological activities in aging cell [88]. Partly because activated sirtuins stimulate the activity of mitochondria, the powerhouses of the cell, and of mitochondrial proteins, they have the potential to regulate neurodegenerative diseases [89,90]. Here, we highlight and discuss the effect of SIRT1 and its activators on AD.

Owing to the multiple targets, SIRT1 plays an important role in neurodegenerative diseases [91]. During normal aging, SIRT1 is responsible for the maintenance of the nervous system and behavior, including regulation of synaptic plasticity and memory processes [92]. Activation of SIRT1 can down-regulate $A \beta$ expression by reducing the formation of APP, and inhibiting RHO protein kinase II to increase the activity of $\alpha$-secretase and finally reduce the production of $A \beta$. Conversely, only inhibiting SIRT2 can have neuroprotective effects [89]. Resveratrol has long been used as a natural SIRT1 activator, and ameliorates AD in multiple ways $[93,94]$. In-vitro studies have shown that resveratrol treatment counteracts $\mathrm{H}_{2} \mathrm{O}_{2}$ induced damage, increases cell viability and delays the formation of A $\beta 42$ oligomers and fibrils in cells [95]. Resveratrol exerts antioxidant effect against AD pathology, where it has been reported to disrupt $A \beta$ aggregation via causing peptide fragmentation [96]. On the other hand, multiple in-vivo studies have indicated that resveratrol suppresses inflammation and inhibits toxicity of misfolded $A \beta$ aggregation. It can rescue $A \beta 42$-induced proliferation and activation of primary astrocytes and up-regulate SIRT1 expression to protect PC12 cells from A $\beta_{25-35}$ neurotoxicity and apoptosis [97]. Simultaneously, a series of in-vitro studies showed that SIRT1 pharmacological activation can prevent amyloid deposition and neurodegeneration in AD [98]. For example, resveratrol protected neurotoxic p 25 transgenic mice from CNS degeneration and cognitive decline, and ameliorated lifespan and cognitive impairment in mouse models [99]. Resveratrol has been shown to increase SIRT1 and AMPK in the brains of most transgenic mice [89].

Sirtuin is also highly conserved in Drosophila melanogaster and over-expression of sirtuin can extend the lifespan in Drosophila, yet some studies have shown contradicting results $[100,101]$. Bollinger et al. explored a resveratrol analogue called resveramorph 1, which has many functional group features similar to resveratrol. Results showed that resveramorph 1 protects synaptic function during acute oxidative stress at low dose and potentially contributes to the protection of synaptic transmission, which indicated that resveramorph 1 might confer its neuroprotective effects in a dose-dependent manner [102]. MPTP (1-Methyl-4-Phenyl-1,2,3,6-Tetrahydropyridine) is a neurotoxin which causes oxidative stress and inflammation in brain. The data showed that resveratrol increased lifespan in Drosophila and further ameliorated MPTP-triggered cell death, histological alterations, behavioral deficits and accumulation of nitric oxide and hydrogen peroxide levels in flies. A brain histology test showed that MPTP induced partial loss of neurons in the cerebral hemisphere rescued by resveratrol treatment, which indicated that the neuroprotective effect of resveratrol can improve oxidative stress and inflammation in the brain [103]. As mentioned above, AD and diabetes mellitus (DM) often coexist in patients, but mechanisms associated with $\mathrm{DM}$ and $\mathrm{AD}$ are bewildering. Nevertheless, some studies showed that Islet amyloid polypeptide (IAPP) can interact and co-deposit with A $\beta$ and tau, thereby contributing to diabetes-associated dementia. This may be a clue to explain the relationship between $\mathrm{AD}$ and DM [104]. A recent study using rat models of diabetes with co-occurring AD, showed that resveratrol significantly increased the Sirt1 expression, inhibited the memory impairment, increased acetylcholinesterase, malondialdehyde, interleukin- $1 \beta$ and interleukin 6 levels, and decreased the levels of choline acetyltransferase (ChAT), superoxide dismutase (SOD), and glutathione [98]. All these 
reports point towards some kind of association between SIRT1 and AD pathology and further supported resveratrol as a potential drug to treat neurodegenerative disease. However, most investigations of resveratrol on $\mathrm{AD}$ were conducted in cell culture or animal $\mathrm{AD}$ models. The lack of information from human clinical studies is the major obstacle in proving the safety and efficacy of resveratrol for the treatment of human AD.

\subsection{JNK Inhibitors}

c-Jun N-terminal kinases (JNKs), first characterized as stress-activated members of the MAPK family [105], are evolutionarily conserved from fruit fly to human, and plays crucial roles in regulating a wide range of cellular activities including proliferation, differentiation and migration, and especially cell death, making it one of the most important targets in pharmacological screening strategies [106,107]. It seems that JNK is a key mediator of the $A \beta$-death pathway. Evidence proved that the early activation of JNK is always accompanied by the deposition of $A \beta$ in the brain; JNK also co-localized with tau fibrillary tangle; and JNK activity is greater in the AD brains than control brains [108,109]. Study in a mouse AD model showed that electroacupuncture treatment significantly ameliorated the cognitive impairments and downregulated APP expression by inhibiting JNK activation [110]. Jang et al. explored an inhibitor called 1-phenyl-2-pyrimidyl-1H-benzimidazole derivative, which is a protein kinase inhibitor targeting JNK3. Further evidence showed that JNK3 is mainly expressed in the brain, indicating the potential of this compound for the treatment of AD [105]. In Drosophila, researchers expressed high levels of human A $\beta 42$ polypeptide in the differentiating photoreceptor neurons and developed a transgenic model system in Drosophila eye [111]. A Chinese traditional medicinal prescription called KSOP1009 could strongly suppress $A \beta 42$-induced eye degeneration and the locomotive dysfunctions via suppression of the hyperactivation of JNK activity and apoptosis [112]. A recent study found a positive feedback loop of Hippo and JNK signaling which regulates $A \beta$ mediated neurodegeneration. Down-regulation of both signaling pathways can rescue A $\beta$ mediated toxicity [113]. An early study also verified that Lunasin can downregulate JNK signaling dependent cell death in the developing retinal neurons of the Drosophila eye and reduce the mortality rate in AD flies [114]. On the other hand, gut microbiome dysbiosis seems to be related to AD pathology. It was reported that enterobacteria infection in Drosophila AD model declined lifespan, locomotor activity, and induced ROS stress, indicating that intestinal dysbiosis can remotely stimulate proinflammatory responses in the amyloid transgenic fly brain. The enteric infection promotes brain recruitment of hemocytes, which causes the activation of JNK and then the exacerbation of AD [115]. Recently, Chinese researchers developed a compound called GV-971, which targets gut microbiota and suppresses gut bacterial amino acids-shaped neuroinflammation to inhibit AD progression in mouse model, and also showed cognition improvement in a phase 3 clinical trial in China [116]. The advent of this drug makes up for the blank in the absence of new drugs to treat AD for more than a decade. However, we still need stronger evidence to show that gut microbiota may be an instructive therapeutic target for AD.

\subsection{Natural Compounds and Antioxidants Target AD Pathology}

Traditionally, natural plant products have been utilized for the treatment of various types of diseases, and the antioxidant activity they possess often reduces the toxicity induced by $A \beta$ aggregation [117]. Gardenia jasminoides extract ameliorated memory deficits, and decreased the expression of inflammatory genes in AD Drosophila brain, but did not show any positive effects on lifespan extension and $A \beta$ proteins reduction [118]. Treatment with nordihydroguaiaretic acid (NDGA), a phenolic lignin, rescued the shortened lifespan caused by AD in Drosophila. Furthermore, NDGA protected the hippocampal neurons against $A \beta$ peptide induced toxicity by reduction of the oxidative stress [119]. It has been well established that the increased reactive oxygen species (ROS), lipid peroxidation (LPO), and enzymes such as SOD, are the biomarkers of AD pathology [120,121]. In this context, Convolvulus pluricaulis extract (aqueous) offsets tau induced early death and extends the lifespan and diminishes the level of tau protein in tauopathy Drosophila. Meanwhile, C. pluricaulis 
decreased the levels of ROS, LPO and oxidative damage of tau protein [122]. Similarly, luteolin reduced the level of LPO, SOD and inhibited A $\beta 42$ plaque formation in A $\beta 42$ expressing flies [50]. As a potent antioxidant, quercetin was able to effectively clear ROS and showed the beneficial effects in mouse AD model [123]. By modulating the expression of cell cycle related proteins, quercetin extended lifespan and rescued the climbing activity in AD flies. Owing to the fact that quercetin serve as Sirt1 agonist or acetylcholine-esterase (AChE) inhibitor and can target many signaling pathways, including BACE1, JNK signaling and GSK-3 $\beta$ in the brain, it can be safely stated that quercetin can be a useful compound for providing new insights into the treatment of neurodegeneration [124]. Polyphenols have been reported to suppress the activation of microglia and affect nuclear factor-kappaB (NF- $\mathrm{kB}$ ) signaling to reduce inflammation [125]. For example, the exposure of AD flies to kaempferol showed delayed loss of climbing ability, memory, reduced the oxidative stress and acetylcholinesterase activity [126]. Curcumin, a bioactive polyphenolic compound, promoted amyloid fibril conversion by reducing the pre-fibrillar/oligomeric species of $A \beta$ and down-regulating AChE gene expression [127], resulting in a reduced neurotoxicity in Drosophila and also exhibited an inhibitory effect on BACE1 activity [48]. Moreover, treatment with extract of Arabidopsis thaliana showed a lower pro-inflammatory and a higher anti-inflammatory effect. In-vivo, the extract significantly restored the locomotor activity of A $\beta 42$ flies and exhibited neuroprotective effects [125]. Moreover, there are other natural compounds, such as flavonoids including myricetin, morin and rutin, which have been shown, in-vitro, to possess antiamyloidogenic and fibril destabilization activity, as well as being able to act as metal chelators and to suppress oxidative stress [12]. We have summarized the reports using natural compounds on Drosophila AD model in Table 2.

Table 2. Overview of natural compounds acting on Drosophila AD model.

\begin{tabular}{|c|c|c|c|c|}
\hline Drug/Compound & Type of Molecule & Mode of Action & Effects & References \\
\hline Gardenia jasminoides & Herbal extract & $\begin{array}{l}\text { Decreased expression of } \\
\text { inflammatory genes }\end{array}$ & Ameliorated memory deficits & [118] \\
\hline C. pluricaulis extract & Herbal extract & Tau protein & $\begin{array}{l}\text { Lifespan extension, decrease ROS } \\
\text { and LPO level }\end{array}$ & [122] \\
\hline NDGA & Phenolic lignan & $\begin{array}{c}\text { Inhibitor of lipoxygenase, } \\
\text { antioxidant }\end{array}$ & $\begin{array}{l}\text { Lifespan extension, protected the } \\
\text { hippocampal neurons }\end{array}$ & [119] \\
\hline Luteolin & Polyphenols & Inhibition of AChE & $\begin{array}{l}\text { Lifespan extension, rescue } \\
\text { locomotive and prevention of } A \beta 42 \\
\text { plaque }\end{array}$ & [50] \\
\hline Kaempferol & Polyphenols & Antioxidant & $\begin{array}{c}\text { Rescue locomotive, improve } \\
\text { memory and reduced AChE activity }\end{array}$ & [126] \\
\hline Curcumin & Polyphenols & Inhibition BACE1 activity & $\begin{array}{l}\text { Promotes amyloid fibril conversion, } \\
\text { reduced neurotoxicity }\end{array}$ & {$[48,127]$} \\
\hline Arabidopsis thaliana & Polyphenols & $\begin{array}{l}\text { Activation Nrf2 pathway, } \\
\text { antioxidant }\end{array}$ & $\begin{array}{l}\text { Rescue locomotive and } \\
\text { neuroprotective }\end{array}$ & [125] \\
\hline Quercetin & Flavonoid & Cell cycle related proteins & $\begin{array}{l}\text { Lifespan extension, rescue } \\
\text { locomotive and restore } \mathrm{A} \beta \text { induced } \\
\text { perturbation }\end{array}$ & [124] \\
\hline
\end{tabular}

\section{Conclusions}

In past decades, the understanding of the pathological mechanisms of AD has improved, but there are still many basic questions that need to be answered. Here, we summarized recent advances in pharmacological treatment targeting major signaling pathways in Drosophila AD model, providing an exhaustive reference for the future drug development programs for the treatment of AD. Understanding the molecular mechanisms of disease through in-vivo animal model systems will help determine potential therapeutic targets.

Due to the close genetic similarities to humans, Drosophila has been an important resource to investigate neurodegenerative diseases, including AD, Parkinson's and Huntington's disease. Compared to mouse, Drosophila needs less cost and space, and its shorter lifespan makes it possible 
to measure the efficacy of drugs within a reasonable time and allows implementation of a high throughput screen. On the other hand, due to the limitation of Drosophila AD models, it is necessary to develop more realistic AD models by new genome modification technologies, which can achieve better characterization of pathological mechanisms and quickly develop targeted drugs for AD. Unfortunately, no matter what kind of medicine, after dose-dependent and long-term administration, drug resistance or strong side effects often result. Therefore, in drug screening or development, a crucial point is to better understand the crosstalk between AD-related pathways, especially to understand which pathways can interact with each other and then to find relevant targets. Furthermore, the drug combinations need to be screened that can produce a synergistic effect, reduce the dosage of single drug or the cycle of medication, and produce the maximum effect with the lowest toxicity. In this regard, it is crucial to produce less toxic and safe drug candidates in the future.

Author Contributions: X.C. and M.Y. structured the text and content. X.C. and C.S. reviewed the literature and provided intellectual contributions. X.C. and Y.D. generated the figures. X.C., U.G. and M.Y. wrote the manuscript. All authors have read and agreed to the published version of the manuscript.

Funding: This work was supported by The National Natural Science Foundation of China (31771338).

Conflicts of Interest: The authors declare no conflict of interest.

$\begin{array}{ll}\text { Abbreviations } \\ \text { ACh } & \text { Acetylcholine } \\ \text { AChE } & \text { Acetylcholine-esterase } \\ \text { AD } & \text { Alzheimer's disease } \\ \text { AKT } & \text { Protein kinase B } \\ \text { AMPK } & \text { AMP-regulated protein kinase } \\ \text { APP } & \text { Amyloid precursor protein } \\ \text { A } \beta & \text { Amyloid } \beta \\ \text { BACE1 } & \beta \text {-secretase } \\ \text { CDK-5 } & \text { Cyclin-dependent kinase-5 } \\ \text { ChAT } & \text { Choline acetyltransferase } \\ \text { CNS } & \text { Central nervous system } \\ \text { DM } & \text { Diabetes mellitus } \\ \text { dPsn } & \text { Drosophila presenilin } \\ \text { GSK-3 } & \text { Glycogen synthase kinase-3 } \\ \text { HAPP } & \text { Human APP protein } \\ \text { hBACE } & \text { Human } \beta \text {-secreted protein } \\ \text { IGF } & \text { Insulin/Insulin-like growth factor } \\ \text { IIS } & \text { The insulin/IGF-1 signaling pathways } \\ \text { ILPs } & \text { Insulin-like peptides } \\ \text { InR } & \text { Insulin/IGF receptor } \\ \text { JNKs } & \text { c-Jun N-terminal kinases } \\ \text { LPO } & \text { Lipid peroxidation } \\ \text { MARK } & \text { Microtubule affinity regulating kinase } \\ \text { MAPK } & \text { Mitogen-activated protein kinase } \\ \text { MPTP } & \text { 1-Methyl-4-Phenyl-1,2,3,6-Tetrahydropyridine } \\ \text { mTOR } & \text { Mammalian target of rapamycin } \\ \text { NDGA } & \text { Nordihydroguaiaretic acid } \\ \text { NFTs } & \text { Neurofibrillary tangles } \\ \text { NF-kB } & \text { Nuclear factor-kappaB } \\ \text { ROS } & \text { Reactive oxygen species } \\ \text { SOD } & \text { Superoxide dismutase } \\ & \end{array}$




\section{References}

1. Singh, P.P.; Demmitt, B.A.; Nath, R.D.; Brunet, A. The Genetics of Aging: A Vertebrate Perspective. Cell 2019, 177, 200-220. [CrossRef] [PubMed]

2. Long, J.M.; Holtzman, D.M. Alzheimer Disease: An Update on Pathobiology and Treatment Strategies. Cell 2019, 179, 312-339. [CrossRef]

3. Jeon, Y.; Lee, J.H.; Choi, B. Genetic Dissection of Alzheimer's Disease Using Drosophila Models. Int. J. Mol. Sci. 2020, 21, 884. [CrossRef] [PubMed]

4. Sharma, P.; Srivastava, P.; Seth, A.; Tripathi, P.N.; Banerjee, A.G.; Shrivastava, S.K. Comprehensive review of mechanisms of pathogenesis involved in Alzheimer's disease and potential therapeutic strategies. Prog. Neurobiol. 2019, 174, 53-89. [CrossRef] [PubMed]

5. Hardy, J.; Selkoe, D.J. The amyloid hypothesis of Alzheimer's disease: Progress and problems on the road to therapeutics. Science 2002, 297, 353-356. [CrossRef] [PubMed]

6. Karran, E.; Mercken, M.; De Strooper, B. The amyloid cascade hypothesis for Alzheimer's disease: An appraisal for the development of therapeutics. Nat. Rev. Drug Discov. 2011, 10, 698-712. [CrossRef]

7. Scholz, T.; Mandelkow, E. Transport and diffusion of Tau protein in neurons. Cell. Mol. Life Sci. 2014, 71, 3139-3150. [CrossRef]

8. Duan, Y.; Dong, S.; Gu, F.; Hu, Y.; Zhao, Z. Advances in the pathogenesis of Alzheimer's disease: Focusing on tau-mediated neurodegeneration. Transl. Neurodegener. 2012, 1, 24. [CrossRef]

9. Bossy-Wetzel, E.; Schwarzenbacher, R.; Lipton, S.A. Molecular pathways to neurodegeneration. Nat. Med. 2004, 10, S2-S9. [CrossRef]

10. Nizzari, M.; Thellung, S.; Corsaro, A.; Villa, V.; Pagano, A.; Porcile, C.; Russo, C.; Florio, T. Neurodegeneration in Alzheimer disease: Role of amyloid precursor protein and presenilin 1 intracellular signaling. J. Toxicol. 2012, 2012, 187297. [CrossRef]

11. Vermunt, L.; Sikkes, S.A.M.; van den Hout, A.; Handels, R.; Bos, I.; van der Flier, W.M.; Kern, S.; Ousset, P.J.; Maruff, P.; Skoog, I.; et al. Duration of preclinical, prodromal, and dementia stages of Alzheimer's disease in relation to age, sex, and APOE genotype. Alzheimer Dement. 2019, 15, 888-898. [CrossRef] [PubMed]

12. Simunkova, M.; Alwasel, S.H.; Alhazza, I.M.; Jomova, K.; Kollar, V.; Rusko, M.; Valko, M. Management of oxidative stress and other pathologies in Alzheimer's disease. Arch. Toxicol. 2019, 93, 2491-2513. [CrossRef] [PubMed]

13. Jalili-Baleh, L.; Babaei, E.; Abdpour, S.; Nasir Abbas Bukhari, S.; Foroumadi, A.; Ramazani, A.; Sharifzadeh, M.; Abdollahi, M.; Khoobi, M. A review on flavonoid-based scaffolds as multi-target-directed ligands (MTDLs) for Alzheimer's disease. Eur. J. Med. Chem. 2018, 152, 570-589. [CrossRef] [PubMed]

14. Kumar, D.; Ganeshpurkar, A.; Kumar, D.; Modi, G.; Gupta, S.K.; Singh, S.K. Secretase inhibitors for the treatment of Alzheimer's disease: Long road ahead. Eur. J. Med. Chem. 2018, 148, 436-452. [CrossRef]

15. Lashley, T.; Schott, J.M.; Weston, P.; Murray, C.E.; Wellington, H.; Keshavan, A.; Foti, S.C.; Foiani, M.; Toombs, J.; Rohrer, J.D.; et al. Molecular biomarkers of Alzheimer's disease: Progress and prospects. Dis. Mod. Mech. 2018, 11, dmm031781. [CrossRef]

16. Nakamura, A.; Kaneko, N.; Villemagne, V.L.; Kato, T.; Doecke, J.; Dore, V.; Fowler, C.; Li, Q.X.; Martins, R.; Rowe, C.; et al. High performance plasma amyloid-beta biomarkers for Alzheimer's disease. Nature 2018, 554, 249-254. [CrossRef]

17. Haass, C.; Kaether, C.; Thinakaran, G.; Sisodia, S. Trafficking and proteolytic processing of APP. Cold Spring Harb. Perspect. Med. 2012, 2, a006270. [CrossRef]

18. De Strooper, B.; Karran, E. The Cellular Phase of Alzheimer's Disease. Cell 2016, 164, 603-615. [CrossRef]

19. Selkoe, D.J.; Hardy, J. The amyloid hypothesis of Alzheimer's disease at 25 years. EMBO Mol. Med. 2016, 8, 595-608. [CrossRef]

20. Iqbal, K.; Liu, F.; Gong, C.X. Tau and neurodegenerative disease: The story so far. Nat. Rev. Neurol. 2016, 12, 15-27. [CrossRef]

21. Krishnaswamy, S.; Huang, H.W.; Marchal, I.S.; Ryoo, H.D.; Sigurdsson, E.M. Neuronally expressed anti-tau scFv prevents tauopathy-induced phenotypes in Drosophila models. Neurobiol. Dis. 2020, 137, 104770. [CrossRef] [PubMed]

22. Song, J.X.; Malampati, S.; Zeng, Y.; Durairajan, S.S.K.; Yang, C.B.; Tong, B.C.; Iyaswamy, A.; Shang, W.B.; Sreenivasmurthy, S.G.; Zhu, Z.; et al. A small molecule transcription factor EB activator ameliorates 
beta-amyloid precursor protein and Tau pathology in Alzheimer's disease models. Aging Cell 2020, 19, e13069. [CrossRef] [PubMed]

23. Ballatore, C.; Lee, V.M.; Trojanowski, J.Q. Tau-mediated neurodegeneration in Alzheimer's disease and related disorders. Nat. Rev. Neurosci. 2007, 8, 663-672. [CrossRef] [PubMed]

24. Liu, S.L.; Wang, C.; Jiang, T.; Tan, L.; Xing, A.; Yu, J.T. The Role of Cdk5 in Alzheimer's Disease. Mol. Neurobiol. 2016, 53, 4328-4342. [CrossRef] [PubMed]

25. Oddo, S.; Caccamo, A.; Cheng, D.; Jouleh, B.; Torp, R.; LaFerla, F.M. Genetically augmenting tau levels does not modulate the onset or progression of Abeta pathology in transgenic mice. J. Neurochem. 2007, 102, 1053-1063. [CrossRef]

26. Oddo, S.; Caccamo, A.; Tseng, B.; Cheng, D.; Vasilevko, V.; Cribbs, D.H.; LaFerla, F.M. Blocking Abeta42 accumulation delays the onset and progression of tau pathology via the $C$ terminus of heat shock protein70-interacting protein: A mechanistic link between Abeta and tau pathology. J. Neurosci. 2008, 28, 12163-12175. [CrossRef] [PubMed]

27. Sabbagh, J.J.; Kinney, J.W.; Cummings, J.L. Animal systems in the development of treatments for Alzheimer's disease: Challenges, methods, and implications. Neurobiol. Aging 2013, 34, 169-183. [CrossRef]

28. Esquerda-Canals, G.; Montoliu-Gaya, L.; Guell-Bosch, J.; Villegas, S. Mouse Models of Alzheimer's Disease. J. Alzheimer Dis. 2017, 57, 1171-1183. [CrossRef]

29. Griffin, E.F.; Caldwell, K.A.; Caldwell, G.A. Genetic and Pharmacological Discovery for Alzheimer's Disease Using Caenorhabditis elegans. ACS Chem. Neurosci. 2017, 8, 2596-2606. [CrossRef]

30. Piper, M.D.W.; Partridge, L. Drosophila as a model for ageing. Biochim. Biophys. Acta Mol. Basis Dis. 2018, 1864, 2707-2717. [CrossRef]

31. Fernandez-Funez, P.; de Mena, L.; Rincon-Limas, D.E. Modeling the complex pathology of Alzheimer's disease in Drosophila. Exp. Neurol. 2015, 274, 58-71. [CrossRef] [PubMed]

32. Muqit, M.M.; Feany, M.B. Modelling neurodegenerative diseases in Drosophila: A fruitful approach? Nat. Rev. Neurosci. 2002, 3, 237-243. [CrossRef] [PubMed]

33. Fortini, M.E.; Skupski, M.P.; Boguski, M.S.; Hariharan, I.K. A survey of human disease gene counterparts in the Drosophila genome. J. Cell Biol. 2000, 150, F23-F30. [CrossRef] [PubMed]

34. Sofola, O.; Kerr, F.; Rogers, I.; Killick, R.; Augustin, H.; Gandy, C.; Allen, M.J.; Hardy, J.; Lovestone, S.; Partridge, L. Inhibition of GSK-3 ameliorates Abeta pathology in an adult-onset Drosophila model of Alzheimer's disease. PLoS Genet. 2010, 6, e1001087. [CrossRef] [PubMed]

35. Carmine-Simmen, K.; Proctor, T.; Tschape, J.; Poeck, B.; Triphan, T.; Strauss, R.; Kretzschmar, D. Neurotoxic effects induced by the Drosophila amyloid-beta peptide suggest a conserved toxic function. Neurobiol. Dis. 2009, 33, 274-281. [CrossRef] [PubMed]

36. Greeve, I.; Kretzschmar, D.; Tschape, J.A.; Beyn, A.; Brellinger, C.; Schweizer, M.; Nitsch, R.M.; Reifegerste, R. Age-dependent neurodegeneration and Alzheimer-amyloid plaque formation in transgenic Drosophila. J. Neurosci. 2004, 24, 3899-3906. [CrossRef]

37. Crowther, D.C.; Kinghorn, K.J.; Miranda, E.; Page, R.; Curry, J.A.; Duthie, F.A.; Gubb, D.C.; Lomas, D.A. Intraneuronal Abeta, non-amyloid aggregates and neurodegeneration in a Drosophila model of Alzheimer's disease. Neuroscience 2005, 132, 123-135. [CrossRef]

38. Ye, Y.; Fortini, M.E. Apoptotic activities of wild-type and Alzheimer's disease-related mutant presenilins in Drosophila melanogaster. J. Cell Biol. 1999, 146, 1351-1364. [CrossRef]

39. Bergkvist, L.; Sandin, L.; Kagedal, K.; Brorsson, A.C. AbetaPP processing results in greater toxicity per amount of Abeta1-42 than individually expressed and secreted Abeta1-42 in Drosophila melanogaster. Biol. Open 2016, 5, 1030-1039. [CrossRef]

40. Naseri, N.N.; Wang, H.; Guo, J.; Sharma, M.; Luo, W. The complexity of tau in Alzheimer's disease. Neurosci. Lett. 2019, 705, 183-194. [CrossRef]

41. Mudher, A.; Lovestone, S. Alzheimer's disease-do tauists and baptists finally shake hands? Trends Neurosci. 2002, 25, 22-26. [CrossRef]

42. Wittmann, C.W.; Wszolek, M.F.; Shulman, J.M.; Salvaterra, P.M.; Lewis, J.; Hutton, M.; Feany, M.B. Tauopathy in Drosophila: Neurodegeneration without neurofibrillary tangles. Science 2001, 293, 711-714. [CrossRef] [PubMed] 
43. Chatterjee, S.; Sang, T.K.; Lawless, G.M.; Jackson, G.R. Dissociation of tau toxicity and phosphorylation: Role of GSK-3beta, MARK and Cdk5 in a Drosophila model. Hum. Mol. Genet. 2009, 18, 164-177. [CrossRef] [PubMed]

44. Iijima, K.; Gatt, A.; Iijima-Ando, K. Tau Ser262 phosphorylation is critical for Abeta42-induced tau toxicity in a transgenic Drosophila model of Alzheimer's disease. Hum. Mol. Genet. 2010, 19, 2947-2957. [CrossRef] [PubMed]

45. Iijima-Ando, K.; Sekiya, M.; Maruko-Otake, A.; Ohtake, Y.; Suzuki, E.; Lu, B.; Iijima, K.M. Loss of axonal mitochondria promotes tau-mediated neurodegeneration and Alzheimer's disease-related tau phosphorylation via PAR-1. PLoS Genet. 2012, 8, e1002918. [CrossRef] [PubMed]

46. Chakraborty, R.; Vepuri, V.; Mhatre, S.D.; Paddock, B.E.; Miller, S.; Michelson, S.J.; Delvadia, R.; Desai, A.; Vinokur, M.; Melicharek, D.J.; et al. Characterization of a Drosophila Alzheimer's disease model: Pharmacological rescue of cognitive defects. PLoS ONE 2011, 6, e20799. [CrossRef]

47. Caesar, I.; Jonson, M.; Nilsson, K.P.; Thor, S.; Hammarstrom, P. Curcumin promotes A-beta fibrillation and reduces neurotoxicity in transgenic Drosophila. PLoS ONE 2012, 7, e31424. [CrossRef]

48. Zhang, B.; Li, Q.; Chu, X.; Sun, S.; Chen, S. Salidroside reduces tau hyperphosphorylation via up-regulating GSK-3beta phosphorylation in a tau transgenic Drosophila model of Alzheimer's disease. Transl. Neurodegener. 2016, 5, 21. [CrossRef]

49. Ali, F.; Rahul Jyoti, S.; Naz, F.; Ashafaq, M.; Shahid, M.; Siddique, Y.H. Therapeutic potential of luteolin in transgenic Drosophila model of Alzheimer's disease. Neurosci. Lett. 2019, 692, 90-99. [CrossRef]

50. Bedse, G.; Di Domenico, F.; Serviddio, G.; Cassano, T. Aberrant insulin signaling in Alzheimer's disease: Current knowledge. Front. Neurosci. 2015, 9, 204. [CrossRef]

51. De la Monte, S.M. Insulin Resistance and Neurodegeneration: Progress Towards the Development of New Therapeutics for Alzheimer's Disease. Drugs 2017, 77, 47-65. [CrossRef] [PubMed]

52. Wang, J.; Gallagher, D.; DeVito, L.M.; Cancino, G.I.; Tsui, D.; He, L.; Keller, G.M.; Frankland, P.W.; Kaplan, D.R.; Miller, F.D. Metformin activates an atypical PKC-CBP pathway to promote neurogenesis and enhance spatial memory formation. Cell Stem Cell 2012, 11, 23-35. [CrossRef]

53. Qiu, W.Q.; Folstein, M.F. Insulin, insulin-degrading enzyme and amyloid-beta peptide in Alzheimer's disease: Review and hypothesis. Neurobiol. Aging 2006, 27, 190-198. [CrossRef] [PubMed]

54. Huang, Y.; Wan, Z.; Wang, Z.; Zhou, B. Insulin signaling in Drosophila melanogaster mediates Abeta toxicity. Commun. Biol. 2019, 2, 13. [CrossRef] [PubMed]

55. Manning, B.D.; Toker, A. AKT/PKB Signaling: Navigating the Network. Cell 2017, 169, 381-405. [CrossRef] [PubMed]

56. Wu, Q.; Lian, T.; Fan, X.; Song, C.; Gaur, U.; Mao, X.; Yang, D.; Piper, M.D.W.; Yang, M. 2,5-Dimethyl-Celecoxib Extends Drosophila Life Span via a Mechanism That Requires Insulin and Target of Rapamycin Signaling. J. Gerontol. 2017, 72, 1334-1341.

57. Chen, Y.R.; Li, Y.H.; Hsieh, T.C.; Wang, C.M.; Cheng, K.C.; Wang, L.; Lin, T.Y.; Cheung, C.H.A.; Wu, C.L.; Chiang, H. Aging-induced Akt activation involves in aging-related pathologies and Abeta-induced toxicity. Aging Cell 2019, 18, e12989. [CrossRef]

58. Fan, L.; Qiu, X.X.; Zhu, Z.Y.; Lv, J.L.; Lu, J.; Mao, F.; Zhu, J.; Wang, J.Y.; Guan, X.W.; Chen, J.; et al. Nitazoxanide, an anti-parasitic drug, efficiently ameliorates learning and memory impairments in AD model mice. Acta Pharmacol. Sin. 2019, 40, 1279-1291. [CrossRef]

59. Zhang, B.; Wang, Y.; Li, H.; Xiong, R.; Zhao, Z.; Chu, X.; Li, Q.; Sun, S.; Chen, S. Neuroprotective effects of salidroside through PI3K/Akt pathway activation in Alzheimer's disease models. Drug Des. Dev. Ther. 2016, $10,1335-1343$.

60. Hwang, S.; Jeong, H.; Hong, E.H.; Joo, H.M.; Cho, K.S.; Nam, S.Y. Low-dose ionizing radiation alleviates Abeta42-induced cell death via regulating AKT and p38 pathways in Drosophila Alzheimer's disease models. Biol. Open 2019, 8. [CrossRef]

61. Beurel, E.; Grieco, S.F.; Jope, R.S. Glycogen synthase kinase-3 (GSK3): Regulation, actions, and diseases. Pharmacol. Therap. 2015, 148, 114-131. [CrossRef] [PubMed]

62. Lauretti, E.; Dincer, O.; Pratico, D. Glycogen synthase kinase-3 signaling in Alzheimer's disease. Biochim. Biophys. Acta Mol. Cell Res. 2020, 1867, 118664. [CrossRef] [PubMed]

63. Llorens-Martin, M.; Jurado, J.; Hernandez, F.; Avila, J. GSK-3beta, a pivotal kinase in Alzheimer disease. Front. Mol. Neurosci. 2014, 7, 46. [PubMed] 
64. Sofola-Adesakin, O.; Castillo-Quan, J.I.; Rallis, C.; Tain, L.S.; Bjedov, I.; Rogers, I.; Li, L.; Martinez, P.; Khericha, M.; Cabecinha, M.; et al. Lithium suppresses Abeta pathology by inhibiting translation in an adult Drosophila model of Alzheimer's disease. Front. Aging Neurosci. 2014, 6, 190. [CrossRef] [PubMed]

65. Zhao, N.; Sun, C.; Zheng, M.; Liu, S.; Shi, R. Amentoflavone suppresses amyloid beta1-42 neurotoxicity in Alzheimer's disease through the inhibition of pyroptosis. Life Sci. 2019, 239, 117043. [CrossRef] [PubMed]

66. Ly, P.T.; Wu, Y.; Zou, H.; Wang, R.; Zhou, W.; Kinoshita, A.; Zhang, M.; Yang, Y.; Cai, F.; Woodgett, J.; et al. Inhibition of GSK3beta-mediated BACE1 expression reduces Alzheimer-associated phenotypes. J. Clin. Investig. 2013, 123, 224-235. [CrossRef] [PubMed]

67. Cuesto, G.; Jordan-Alvarez, S.; Enriquez-Barreto, L.; Ferrus, A.; Morales, M.; Acebes, A. GSK3beta inhibition promotes synaptogenesis in Drosophila and mammalian neurons. PLoS ONE 2015, 10, e0118475.

68. Pandey, M.K.; DeGrado, T.R. Glycogen Synthase Kinase-3 (GSK-3)-Targeted Therapy and Imaging. Theranostics 2016, 6, 571-593. [CrossRef]

69. Saxton, R.A.; Sabatini, D.M. mTOR Signaling in Growth, Metabolism, and Disease. Cell 2017, 169, $361-371$. [CrossRef]

70. Zoncu, R.; Efeyan, A.; Sabatini, D.M. mTOR: From growth signal integration to cancer, diabetes and ageing. Nat. Rev. Mol. Cell Biol. 2011, 12, 21-35. [CrossRef]

71. Wullschleger, S.; Loewith, R.; Hall, M.N. TOR signaling in growth and metabolism. Cell 2006, 124, 471-484. [CrossRef] [PubMed]

72. Maiese, K. Targeting molecules to medicine with $\mathrm{mTOR}$, autophagy and neurodegenerative disorders. Br. J. Clin. Pharmacol. 2016, 82, 1245-1266. [CrossRef] [PubMed]

73. Hoeffer, C.A.; Klann, E. mTOR signaling: At the crossroads of plasticity, memory and disease. Trends Neurosci. 2010, 33, 67-75. [CrossRef]

74. Spilman, P.; Podlutskaya, N.; Hart, M.J.; Debnath, J.; Gorostiza, O.; Bredesen, D.; Richardson, A.; Strong, R.; Galvan, V. Inhibition of mTOR by rapamycin abolishes cognitive deficits and reduces amyloid-beta levels in a mouse model of Alzheimer's disease. PLoS ONE 2010, 5, e9979. [CrossRef] [PubMed]

75. Lipton, J.O.; Sahin, M. The neurology of mTOR. Neuron 2014, 84, 275-291. [CrossRef] [PubMed]

76. Cai, Z.; Yan, L.J. Rapamycin, Autophagy, and Alzheimer's Disease. J. Biochem. Pharmacol. Res. 2013, 1, 84-90.

77. Lin, A.L.; Jahrling, J.B.; Zhang, W.; DeRosa, N.; Bakshi, V.; Romero, P.; Galvan, V.; Richardson, A. Rapamycin rescues vascular, metabolic and learning deficits in apolipoprotein $\mathrm{E} 4$ transgenic mice with pre-symptomatic Alzheimer's disease. J. Cereb. Blood Flow Metab. 2017, 37, 217-226. [CrossRef]

78. Liu, W.; Guo, J.; Mu, J.; Tian, L.; Zhou, D. Rapamycin Protects Sepsis-Induced Cognitive Impairment in Mouse Hippocampus by Enhancing Autophagy. Cell. Mol. Neurobiol. 2017, 37, 1195-1205. [CrossRef]

79. Halloran, J.; Hussong, S.A.; Burbank, R.; Podlutskaya, N.; Fischer, K.E.; Sloane, L.B.; Austad, S.N.; Strong, R.; Richardson, A.; Hart, M.J.; et al. Chronic inhibition of mammalian target of rapamycin by rapamycin modulates cognitive and non-cognitive components of behavior throughout lifespan in mice. Neuroscience 2012, 223, 102-113. [CrossRef]

80. Perluigi, M.; Di Domenico, F.; Butterfield, D.A. mTOR signaling in aging and neurodegeneration: At the crossroad between metabolism dysfunction and impairment of autophagy. Neurobiol. Dis. 2015, 84, 39-49. [CrossRef]

81. Maiese, K. Taking aim at Alzheimer's disease through the mammalian target of rapamycin. Ann. Med. 2014, 46, 587-596. [CrossRef] [PubMed]

82. Jin, M.M.; Wang, F.; Qi, D.; Liu, W.W.; Gu, C.; Mao, C.J.; Yang, Y.P.; Zhao, Z.; Hu, L.F.; Liu, C.F. A Critical Role of Autophagy in Regulating Microglia Polarization in Neurodegeneration. Front. Aging Neurosci. 2018, 10, 378. [CrossRef] [PubMed]

83. Khurana, V.; Lu, Y.; Steinhilb, M.L.; Oldham, S.; Shulman, J.M.; Feany, M.B. TOR-mediated cell-cycle activation causes neurodegeneration in a Drosophila tauopathy model. Curr. Biol. 2006, 16, 230-241. [CrossRef] [PubMed]

84. Caccamo, A.; Majumder, S.; Richardson, A.; Strong, R.; Oddo, S. Molecular interplay between mammalian target of rapamycin (mTOR), amyloid-beta, and Tau: Effects on cognitive impairments. J. Biol. Chem. 2010, 285, 13107-13120. [CrossRef] [PubMed]

85. Bjedov, I.; Toivonen, J.M.; Kerr, F.; Slack, C.; Jacobson, J.; Foley, A.; Partridge, L. Mechanisms of life span extension by rapamycin in the fruit fly Drosophila melanogaster. Cell Metab. 2010, 11, 35-46. [CrossRef] 
86. Gaur, U.; Tu, J.; Li, D.; Gao, Y.; Lian, T.; Sun, B.; Yang, D.; Fan, X.; Yang, M. Molecular evolutionary patterns of NAD+/Sirtuin aging signaling pathway across taxa. PLoS ONE 2017, 12, e0182306. [CrossRef]

87. Guarente, L. Introduction: Sirtuins in aging and diseases. Methods Mol. Biol. Clifton N. J. 2013, 1077, 3-10.

88. Scuderi, C.; Stecca, C.; Bronzuoli, M.R.; Rotili, D.; Valente, S.; Mai, A.; Steardo, L. Sirtuin modulators control reactive gliosis in an in vitro model of Alzheimer's disease. Front. Pharmacol. 2014, 5, 89. [CrossRef]

89. Balcerczyk, A.; Pirola, L. Therapeutic potential of activators and inhibitors of sirtuins. BioFactors Oxford Eng. 2010, 36, 383-393. [CrossRef]

90. Anekonda, T.S.; Reddy, P.H. Neuronal protection by sirtuins in Alzheimer's disease. J. Neurochem. 2006, 96, 305-313. [CrossRef]

91. Gomes, B.A.Q.; Silva, J.P.B. Neuroprotective Mechanisms of Resveratrol in Alzheimer's Disease: Role of SIRT1. Oxid. Med. Cell. Longev. 2018, 2018, 8152373. [CrossRef]

92. Chen, Y.; Shi, G.W.; Liang, Z.M.; Sheng, S.Y.; Shi, Y.S.; Peng, L.; Wang, Y.P.; Wang, F.; Zhang, X.M. Resveratrol improves cognition and decreases amyloid plaque formation in Tg6799 mice. Mol. Med. Rep. 2019, 19, 3783-3790. [CrossRef]

93. Lan, J.S.; Liu, Y.; Hou, J.W.; Yang, J.; Zhang, X.Y.; Zhao, Y.; Xie, S.S.; Ding, Y.; Zhang, T. Design, synthesis and evaluation of resveratrol-indazole hybrids as novel monoamine oxidases inhibitors with amyloid-beta aggregation inhibition. Bioorg. Chem. 2018, 76, 130-139. [CrossRef] [PubMed]

94. Albani, D.; Polito, L.; Batelli, S.; De Mauro, S.; Fracasso, C.; Martelli, G.; Colombo, L.; Manzoni, C.; Salmona, M.; Caccia, S.; et al. The SIRT1 activator resveratrol protects SK-N-BE cells from oxidative stress and against toxicity caused by alpha-synuclein or amyloid-beta (1-42) peptide. J. Neurochem. 2009, 110, 1445-1456. [CrossRef]

95. Al-Edresi, S.; Alsalahat, I.; Freeman, S.; Aojula, H.; Penny, J. Resveratrol-mediated cleavage of amyloid $\beta 1-42$ peptide; potential relevance to Alzheimer's disease. Neurobiol. Aging 2020, 94, 24-33. [CrossRef]

96. Zhang, Y.; Anoopkumar-Dukie, S.; Arora, D.; Davey, A.K. Review of the anti-inflammatory effect of SIRT1 and SIRT2 modulators on neurodegenerative diseases. Eur. J. Pharmacol. 2020, 867, 172847. [CrossRef]

97. Ma, X.; Sun, Z.; Han, X.; Li, S.; Jiang, X.; Chen, S.; Zhang, J.; Lu, H. Neuroprotective Effect of Resveratrol via Activation of Sirt1 Signaling in a Rat Model of Combined Diabetes and Alzheimer's Disease. Front. Neurosci. 2019, 13, 1400. [CrossRef]

98. Yang, H.; Zhang, W.; Pan, H.; Feldser, H.G.; Lainez, E.; Miller, C.; Leung, S.; Zhong, Z.; Zhao, H.; Sweitzer, S.; et al. SIRT1 activators suppress inflammatory responses through promotion of p65 deacetylation and inhibition of NF-kappaB activity. PLoS ONE 2012, 7, e46364.

99. Wood, J.G.; Schwer, B.; Wickremesinghe, P.C.; Hartnett, D.A.; Burhenn, L.; Garcia, M.; Li, M.; Verdin, E.; Helfand, S.L. Sirt4 is a mitochondrial regulator of metabolism and lifespan in Drosophila melanogaster. Proc. Natl. Acad. Sci. USA 2018, 115, 1564-1569. [CrossRef] [PubMed]

100. Burnett, C.; Valentini, S.; Cabreiro, F.; Goss, M.; Somogyvári, M.; Piper, M.D.; Hoddinott, M.; Sutphin, G.L.; Leko, V.; McElwee, J.J.; et al. Absence of effects of Sir2 overexpression on lifespan in C. elegans and Drosophila. Nature 2011, 477, 482-485. [CrossRef]

101. Bollinger, W.L.; St Germain, E.J.; Maki, S.L. Resveratrol-Inspired Bridged Bicyclic Compounds: A New Compound Class for the Protection of Synaptic Function from Acute Oxidative Stress. ACS Chem. Neurosci. 2019, 10, 221-225. [CrossRef] [PubMed]

102. Abolaji, A.O.; Adedara, A.O.; Adie, M.A.; Vicente-Crespo, M.; Farombi, E.O. Resveratrol prolongs lifespan and improves 1-methyl-4-phenyl-1,2,3,6-tetrahydropyridine-induced oxidative damage and behavioural deficits in Drosophila melanogaster. Biochem. Biophys. Res. Commun. 2018, 503, 1042-1048. [CrossRef] [PubMed]

103. Raimundo, A.F.; Ferreira, S.; Martins, I.C.; Menezes, R. Islet Amyloid Polypeptide: A Partner in Crime With $\mathrm{A} \beta$ in the Pathology of Alzheimer's Disease. Front. Mol. Neurosci. 2020, 13, 35. [CrossRef]

104. Davis, R.J. Signal transduction by the JNK group of MAP kinases. Cell 2000, 103, 239-252. [CrossRef]

105. Bogoyevitch, M.A.; Ngoei, K.R.; Zhao, T.T.; Yeap, Y.Y.; Ng, D.C. c-Jun N-terminal kinase (JNK) signaling: Recent advances and challenges. Biochim. Biophys. Acta 2010, 1804, 463-475. [CrossRef] [PubMed]

106. Li, G.; Qi, W.; Li, X.; Zhao, J.; Luo, M.; Chen, J. Recent Advances in c-Jun N-terminal Kinase (JNK) Inhibitors. Curr. Med. Chem. 2020. [CrossRef]

107. Borsello, T.; Forloni, G. JNK signalling: A possible target to prevent neurodegeneration. Curr. Pharma. Des. 2007, 13, 1875-1886. [CrossRef] 
108. Bowers, S.; Truong, A.P.; Jeffrey Neitz, R.; Hom, R.K.; Sealy, J.M.; Probst, G.D.; Quincy, D.; Peterson, B.; Chan, W.; Galemmo, R.A., Jr.; et al. Design and synthesis of brain penetrant selective JNK inhibitors with improved pharmacokinetic properties for the prevention of neurodegeneration. Bioorg. Med. Chem. Lett. 2011, 21, 5521-5527. [CrossRef]

109. Tang, Y.; Xu, A.; Shao, S.; Zhou, Y.; Xiong, B.; Li, Z. Electroacupuncture Ameliorates Cognitive Impairment by Inhibiting the JNK Signaling Pathway in a Mouse Model of Alzheimer's Disease. Front. Aging Neurosci. 2020, 12, 23. [CrossRef]

110. Wang, X.; Perumalsamy, H.; Kwon, H.W.; Na, Y.E.; Ahn, Y.J. Effects and possible mechanisms of action of acacetin on the behavior and eye morphology of Drosophila models of Alzheimer's disease. Sci. Rep. 2015, 5, 16127. [CrossRef]

111. Hong, Y.K.; Park, S.H.; Lee, S.; Hwang, S.; Lee, M.J.; Kim, D.; Lee, J.H.; Han, S.Y.; Kim, S.T.; Kim, Y.K.; et al. Neuroprotective effect of SuHeXiang Wan in Drosophila models of Alzheimer's disease. J. Ethnopharmacol. 2011, 134, 1028-1032. [CrossRef]

112. Irwin, M.; Tare, M.; Singh, A.; Puli, O.R.; Gogia, N.; Riccetti, M.; Deshpande, P.; Kango-Singh, M.; Singh, A. A Positive Feedback Loop of Hippo- and c-Jun-Amino-Terminal Kinase Signaling Pathways Regulates Amyloid-Beta-Mediated Neurodegeneration. Front. Cell Dev. Biol. 2020, 8, 117. [CrossRef] [PubMed]

113. Sarkar, A.; Gogia, N.; Glenn, N.; Singh, A.; Jones, G.; Powers, N.; Srivastava, A.; Kango-Singh, M.; Singh, A. A soy protein Lunasin can ameliorate amyloid-beta 42 mediated neurodegeneration in Drosophila eye. Sci. Rep. 2018, 8, 13545. [CrossRef]

114. Wu, S.C.; Cao, Z.S.; Chang, K.M.; Juang, J.L. Intestinal microbial dysbiosis aggravates the progression of Alzheimer's disease in Drosophila. Nat. Commun. 2017, 8, 24. [CrossRef] [PubMed]

115. Wang, X.; Sun, G.; Feng, T.; Zhang, J.; Huang, X.; Wang, T.; Xie, Z.; Chu, X.; Yang, J.; Wang, H.; et al. Sodium oligomannate therapeutically remodels gut microbiota and suppresses gut bacterial amino acids-shaped neuroinflammation to inhibit Alzheimer's disease progression. Cell Res. 2019, 29, 787-803. [CrossRef] [PubMed]

116. Lee, S.; Bang, S.M.; Lee, J.W.; Cho, K.S. Evaluation of traditional medicines for neurodegenerative diseases using Drosophila models. Evid.-Based Complement. Altern. Med. 2014, 2014, 967462. [CrossRef] [PubMed]

117. Ma, W.W.; Tao, Y.; Wang, Y.Y.; Peng, I.F. Effects of Gardenia jasminoides extracts on cognition and innate immune response in an adult Drosophila model of Alzheimer's disease. Chin. J. Nat. Med. 2017, 15, 899-904. [CrossRef]

118. Siddique, Y.H.; Ali, F. Protective effect of nordihydroguaiaretic acid (NDGA) on the transgenic Drosophila model of Alzheimer's disease. Chem.-Biol. Interact. 2017, 269, 59-66. [CrossRef]

119. Moreira, P.I.; Santos, M.S.; Oliveira, C.R.; Shenk, J.C.; Nunomura, A.; Smith, M.A.; Zhu, X.; Perry, G. Alzheimer disease and the role of free radicals in the pathogenesis of the disease. CNS Neurol. Disord. Drug Targ. 2008, 7, 3-10.

120. Silva-Adaya, D.; Perez-De La Cruz, V.; Herrera-Mundo, M.N.; Mendoza-Macedo, K.; Villeda-Hernandez, J.; Binienda, Z.; Ali, S.F.; Santamaria, A. Excitotoxic damage, disrupted energy metabolism, and oxidative stress in the rat brain: Antioxidant and neuroprotective effects of L-carnitine. J. Neurochem. 2008, 105, 677-689. [CrossRef]

121. Kizhakke, P.A.; Olakkaran, S.; Antony, A.; Tilagul, K.S.; Hunasanahally, P.G. Convolvulus pluricaulis (Shankhapushpi) ameliorates human microtubule-associated protein tau (hMAPtau) induced neurotoxicity in Alzheimer's disease Drosophila model. J. Chem. Neuroanat. 2019, 95, 115-122. [CrossRef] [PubMed]

122. Sabogal-Guaqueta, A.M.; Munoz-Manco, J.I.; Ramirez-Pineda, J.R.; Lamprea-Rodriguez, M.; Osorio, E.; Cardona-Gomez, G.P. The flavonoid quercetin ameliorates Alzheimer's disease pathology and protects cognitive and emotional function in aged triple transgenic Alzheimer's disease model mice. Neuropharmacology 2015, 93, 134-145. [CrossRef] [PubMed]

123. Kong, Y.; Li, K.; Fu, T.; Wan, C.; Zhang, D.; Song, H.; Zhang, Y.; Liu, N.; Gan, Z.; Yuan, L. Quercetin ameliorates Abeta toxicity in Drosophila AD model by modulating cell cycle-related protein expression. Oncotarget 2016, 7, 67716-67731. [CrossRef] [PubMed]

124. Mattioli, R.; Francioso, A. Anti-Inflammatory Activity of A Polyphenolic Extract from Arabidopsis thaliana in In Vitro and In Vivo Models of Alzheimer's Disease. Int. J. Mol. Sci. 2019, 20, 708. [CrossRef] [PubMed] 
125. Beg, T.; Jyoti, S.; Naz, F.; Rahul Ali, F.; Ali, S.K.; Reyad, A.M.; Siddique, Y.H. Protective Effect of Kaempferol on the Transgenic Drosophila Model of Alzheimer's Disease. CNS Neurol. Dis. Drug Targ. 2018, 17, 421-429. [CrossRef] [PubMed]

126. Akinyemi, A.J.; Oboh, G.; Ogunsuyi, O.; Abolaji, A.O.; Udofia, A. Curcumin-supplemented diets improve antioxidant enzymes and alter acetylcholinesterase genes expression level in Drosophila melanogaster model. Metab. Brain Dis. 2018, 33, 369-375. [CrossRef] [PubMed]

127. Wang, X.; Kim, J.R.; Lee, S.B.; Kim, Y.J.; Jung, M.Y.; Kwon, H.W.; Ahn, Y.J. Effects of curcuminoids identified in rhizomes of Curcuma longa on BACE-1 inhibitory and behavioral activity and lifespan of Alzheimer's disease Drosophila models. BMC Complement. Altern. Med. 2014, 14, 88. [CrossRef]

(C) 2020 by the authors. Licensee MDPI, Basel, Switzerland. This article is an open access article distributed under the terms and conditions of the Creative Commons Attribution (CC BY) license (http://creativecommons.org/licenses/by/4.0/). 